\title{
PENGARUH BUKTI FISIK, LAYANAN, DAN RELIGIUSITAS TERHADAP LOYALITAS DENGAN KEPUASAN SEBAGAI INTERVENING
}

\author{
Lailizakiatul Makrifah $^{1}$, Yudha Trishananto ${ }^{2}$ \\ 1,2IAIN Salatiga, lailizakiatul@gmail.com; yudhatrishananto@iainsalatiga.ac.id
}

\begin{abstract}
ABSTRAK
Era modern ditandai dengan perilaku seseorang yang melakukan segala hal dengan ditujukan untuk mengikuti zaman, salah satunya dalam berbusana. Tujuan dari penelitian ini adalah untuk mengetahui seberapa besar pengaruh bukti fisik dan layanan purna jual dikaitkan dengan religiusitas terhadap loyalitas yang dimediasi kepuasan konsumen pada perusahaan busana muslim dengan model busananya yang terkenal, Rabbani. Penelitian ini adalah penelitian kuantitatif deskriptif dengan data primer yang diperoleh dari metode penyebaran kuesioner kepada 96 mahasiswa IAIN Salatiga yang menjadi konsumen Brand Rabbani melalui google form dengan teknik purposive sampling. Berdasarkan hasil uji T dan path analysis menunjukkan bahwa terdapat pengaruh yang positif dan signifikan dari bukti fisik terhadap kepuasan, layanan purna jual terhadap loyalitas, dan kepuasan terhadap loyalitas. Terdapat pula hasil lain yaitu positif dan tidak signifikan yaitu diperoleh dari pengaruh layanan purna jual terhadap kepuasan, religiusitas terhadap kepuasan, bukti fisik terhadap loyalitas, layanan purna jual terhadap loyalitas. Pengaruh negatif dan tidak signifikan didapatkan dari pengaruh religiusitas terhadap loyalitas. Kepuasan tidak mampu menjadi mediasi dari layanan purna jual, bukti fisik dan religiusitas terhadap loyalitas. Maka dari itu, penting untuk Rabbani agar memperhatikan kepuasan konsumen agar retensi perusahaan tetap terjaga.
\end{abstract}

Kata kunci : bukti fisik, layanan purna jual, religiusitas, loyalitas, dan kepuasan.

\begin{abstract}
The modern era is marked by the behavior of someone who does everything aimed at keeping up with the times, one of which is in clothing. The purpose of this study was to determine how much influence physical evidence and after-sales service are associated with religiosity on loyalty mediated by consumer satisfaction at a Muslim fashion company with its famous fashion model, Rabbani. This research is a descriptive quantitative study with primary data obtained from the method of distributing questionnaires to 96 IAIN Salatiga students who are consumers of Brand Rabbani through google form with a purposive sampling technique. Based on the results of the $T$ test and path analysis, it shows that there is a positive and significant effect of physical evidence on satisfaction, after-sales service on loyalty, and satisfaction with loyalty. There are also other results that are positive and insignificant, namely obtained from the effect of after-sales service on satisfaction, religiosity on satisfaction, physical evidence on loyalty, after-sales service on loyalty. The negative and insignificant effect was obtained from the influence of religiosity on loyalty. Satisfaction is unable to mediate after sales service, physical evidence and religiosity towards loyalty. Therefore, it is important for Rabbani to pay attention to customer satisfaction so that company retention is maintained.
\end{abstract}

Keywords : physical evidence, after sale service, religiosity, loyalty, and satisfaction.

Naskah diterima : 07-05-2021, Naskah dipublikasikan : 28-09-2021 


\section{PENDAHULUAN}

Indonesia sebagai negara yang termasuk mayoritas penduduknya adalah umat muslim memiliki potensi untuk pengembangan retail busana muslim (Rasida, 2020). Meskipun, tidak seluruh dari kaum muslim yang ada lantas mengenakan pakaian yang menutup aurat seluruhnya. Namun, pada event tertentu tetap ada satu waktu dimana seluruh umat muslim diwajibkan untuk mengenakan pakaian bebas tetapi sopan menurut agama yang dianut, yaitu agama Islam. Hal tersebut muncul karena dengan adanya era digital yang kian memanas diimbangi dengan modernisasi dalam segala bentuk aspek kehidupan, menuntut seseorang dengan gaya hidup modern untuk mengikuti zaman. Sehingga, pakaian muslim yang seharusnya memiliki aspek penilaian tertentu agar dapat dikatakan sesuai dengan ajaran agama Islam sendiri telah kehilangan jati diri.

Dalam pemikiran anak muda, pakaian syar'i hanya diperuntukkan oleh kalangan ibu-ibu pada umumnya (Rasida, 2020). Dengan adanya permasalah tersebut, lantas menyebabkan persaingan dari berbagai merek busana muslim di Indonesia menjadi kian ketat. Busana trend, mulai dari balita, remaja, dewasa, hingga lansia terdapat cluster model tersendiri dari golongan usianya. Salah satu merek terkenal yang menggandrungi bisnis retail busana muslim dan telah terkenal adalah Rabbani. Sesuai dengan visi dan misi dari Rabbani itu sendiri, dengan menciptakan pasar yang mendunia, menciptakan kepuasan konsumen dimanapun ia berada, dan juga kesediaan model dengan sesuai keinginan konsumen menjadi nilai plus tersendiri pada bidangnya (m.rabbani.co.id, 2021). Meskipun Rabbani telah menempati posisi TOP pada TOP Brand Index kurun waktu 5 tahun terakhir pada tahun 2016-2020, ia tidak serta merta meremehkan kepuasan dan keloyalitasan dari konsumen. Rabbani terus peduli dan meningkatkan kualitas layanan dari perusahaan. Pada kepuasan konsumen dipengaruhi oleh berapa aspek tertentu. Dalam dunia pemasaran, terdapat istilah bauran pemasaran yang disingkat dengan istilah 7P's (product, promotion, price, place, people, process, dan physical evidence) dan kini telah dikembangkan dan ditambahkan variabel layanan purna jual dan komunikasi (Hasan \& Islam, 2020). Kepuasan konsumen terbentuk atas keinginan yang terpenuhi. Pada kenyataannya, produk dengan kriteria 7P's terbaiklah yang akan menempati posisi tertinggi di hati masyarakat. Metode yang tepat akan memudahakan pencapaian target yang sesuai dengan sasaran yang dituju.

Pada sebuah perusahaan, bukti fisik dapat menjadi salah satu bauran pemasaran yang dapat meningkatkan kepuasan dari konsumen secara signifikan. Begitu pula dengan layanan purna jual, layanan yang bagus dapat mendorong konsumen untuk terus menikmati produk yang ditawarkan oleh perusahaan (Othman, Weijun, et al., 2020). Saat ini, tak jarang muslim ataupun muslimah bergaya hidup dengan ditentukan oleh tuntutan zaman bukan akidah islam, baik dalam konsumsi makanan, make up, hingga fashion. Fenomena tersebut dikaitkan dengan variabel islami dengan konteks keagamaan sesuai dengan objek yang telah ditentukan, yaitu religiusitas. Religiusitas merupakan tingkat kedalaman ilmu pada ajaran agama yang dianut oleh seseorang yang ditunjukkan dengan perkataan, dilakukan dengan perbuatan, dan diyakini dalam hati (Munandar \& Sari, 2019).

Berdasarkan penelitian-penelitian terdahulu, ditemukan adanya perbedaan mengenai hasil penelitian tentang bukti fisik. Menurut B. Othman, Weijun, et al. (2020), Hatauruk et al., (2020), Hasan \& Islam (2020), (Othman, Harun, et al., 2020) menyatakan bahwa bukti fisik berpengaruh positif terhadap kepuasan konsumen, berbeda dengan hasil penelitian yang dilakukan oleh (Nasution et al., 2020) dan (Setio \& Wahjudono, 2017) dimana hasilnya mengatakan bahwa variabel bukti fisik tidak berpengaruh terhadap kepuasan konsumen. Penelitian lain mengungkapkan adanya hasil yang positif dan signifikan dengan pengaruh mediasi variabel kepuasan konsumen (Lestari et al., 2021; Olivia \& Ngatno, 2021). Sehingga pelu adanya riset lebih lanjut mengenai variabel terkait guna memperoleh hasil sebagai data penguat dari hasil 
penelitian sebelumnya. Maka dapat dirumuskan sebagai berikut: 1) bagaimana pengaruh bukti fisik, layanan purna jual, dan religiusitas terhadap loyalitas konsumen dan 2) bagimana pengaruh kepuasan konsumen dalam memediasi bukti fisik, layanan purna jual, dan religiusitas terhadap loyalitas konsumen. Berkaitan dengan latar belakang tersebut, peneliti tertarik untuk melakukan penelitian lebih lanjut terkait dengan bukti fisik, layanan purna jual, dan religiusitas terhadap konsumen. Peneliti mengambil studi kasus mahasiswa IAIN Salatiga yang menjadi konsumen Rabbani. Dimana IAIN merupakan kampus islami sehingga lebih cenderung melekat pada pemilihan objek dan variabel terkait. Sehingga layak untuk dijadikan sampel dalam penelitian ini. Penelitian ini mengenai faktor-faktor yang dapat mempengaruhi loyalitas konsumen Rabbani berdasarkan variabel-variabel yang telah ditentukan yaitu bukti fisik, layanan purna jual, dan religiusitas dengan mediasi kepuasan konsumen Rabbani.

\section{KAJIAN LITERATUR \\ TPB (Theory of Planned Behaviour)}

Perilaku seseorang dapat berubah karena beberapa faktor (Ajzen, 2005) meliputi: 1) Keyakinan perilaku (behavioral beliefs), yaitu rasa yakin seseorang pada suatu perilaku yang dinyatakan baik atau buruk. 2) keyakinan normatif (normative beliefs), yaitu keyakinan seseorang akibat pengaruh dari faktor lingkungan dan faktor sosial. 3) norma subjektif (subjektive norms), yaitu motivasi yang didapatkan dari orang lain. 4) keyakinan dapat melakukan sesuatu (control beliefs), yaitu keyakinan yang didapatkan berdasarkan pengalaman yang dilakukan dirinya sendiri atau orang lain. 5) persepsi kemampuan mengontrol (perceived behavioral control), yaitu keyakinan akibat waktu dan fasilitas yang mendukung. 6) niat bertindak (behavioral intention), yaitukeinginan seseorang bertindak sesuai dengan sikap positif yang dimiliki. 7) latar belakang (background), yaitu keyakinan berdasarkan jenis kelamin, sosial, ekonomi, suasana, karakter, pengalaman, dan pengetahuan.

\section{Manajemen Pemasaran}

Manajemen merupakan proses pengelolaan dan pengorganisasian suatu kelompok tertentu dengan tujuan untuk mencapai suatu target tertentu pula (Zainurossalamia, 2020). Pemasaran itu erat hubungannya dengan proses mengidentifikasi dan memenuhi segala keperluan yang menjadi kebutuhan manusia dan masyarakat, mudahnya pemasaran itu usaha untuk memberikan hasil (Arif, 2012). Tujuannya adalah untuk lebih mengenali pelanggan, memahami keinginan konsumen, dan mengetahui kebutuhan dari konsumen itu sendiri. Sehingga, perusahaan memahami bagaimana cara menarik calon konsumen hingga menjadi konsumen yang setia pada perusahaan (Zainurossalamia, 2020).

\section{Bauran Pemasaran}

Dalam mencapai sebuah tujuan, perusahaan memerlukan alat agar sampai pada target yang diinginkan. Bauran pemasaran merupakan tool yang digunakan untuk mempermudah pencapaian tujuan perusahaan yaitu dengan mengombinasikan beberapa elemen yang perlu dipertimbangkan dalam program pemasaran agar hasilnya maksimal (Lupiyoadi, 2002). Elemen tersebut dirangkum dalam 7P's yaitu product, price, people, place, procces, physical evidence, promotion. Namun, memberikan tambahan untuk meningkatkan evaluasi yaitu after sale service dan marketing communication (Khatab et al., 2019).

\section{Bukti Fisik}

Bukti fisik mencakup seluruh aspek pada yang dimiliki penjual meliputi dekorasi ruangan, staf karyawan, dan segala sesuatu yang menyangkut antara penjual dan pembeli saat melakukan transaksi (Othman, Harun, et al., 2020). Bukti fisik dapat diartikan sebagai kemampuan sebuah perusahaan ketika berhadapan langsung dengan konsumen (Yusman \& Yateno, 2021). Menurut (Wicaksono et al., 2021) variabel physical evidence dapat diukur dengan indikator sebagai berikut: 
1. Daya tarik desain gambar produk.

2. Kelengkapan fasilitas.

3. Tingkat kebersihan.

\section{Layanan Purna Jual}

Layanan purna jual merupakan dimensi baru dalam bauran pemasaran yang telah turut mengubah tradisi bisnis semakin maju. Menurut (Jalil, 2011), strategi dari layanan purna jual penyedia layanan terpengaruh karena syarat tertentu seperti layanan, garansi, karakteritstik pelanggan dan sifat produk. Layanan purna jual adalah bentuk tanggung jawab yang diberikan perusahaan kepada konsumen sehingga berperan penting karena dapat menjalin hubungan baik dengan konsumen (Fauziyah \& Tjahjaningsih, 2021). Menurut (Saputro \& Laura, 2020) variabel after sale service diukur dengan indikator sebagai berikut:

1. Garansi.

2. Penyedia aksesoris.

3. Kemudahan dalam mendapatkan suku cadang.

4. Konsultasi lanjutan.

5. Jumlah layanan pusat.

\section{Religiusitas}

Religiusitas adalah kedalaman seseorang pada pemahaman terkait ilmu agama yang dianut nya diikuti luasnya pengetahuan, tindakan yang dilaksanakan, dan sikap toleransi pada pemilik agama yang berbeda. Sedikitnya terdapat empat faktor yang mempengaruhi religiusitas yaitu faktor pendidikan, pengalaman, kehidupan, dan faktor intelektual (Bawono \& Oktaviani, 2016). Terdapat 5 dimensi dalam religiusitas menurut (Trishananto, 2019) yaitu 1) dimensi keimanan yang mengacu pada kepercayaan pada agama yang anut; 2 ) dimensi praktik yaitu meng acu pada komitmen dan ketaatan menjalankan ibadah; 3) dimensi pengalaman yaitu mengacu pada pengalaman yang disyukuri; 4) dimensi pengetahuan agama yaitu meliputi tingkat pengetahuan dan pemahaman pada ajaran agama; dan 5) dimensi konsekuensi yaitu seberapa besar perilaku yang menggambarkan pengaruh dari agamanya. Menurut (Hutagalung et al., 2020) variabel religiusitas dapat diukur dengan indikator sebagai berikut:

1. Keyakinan terhadap agama.

2. Praktik keagamaan.

3. Perasaan religius.

4. Pengetahuan mengenai agama.

5. Religi efek.

\section{Loyalitas Konsumen}

Loyalitas konsumen adalah komitmen seseorang untuk menggunakan kembali suatu produk atau jasa pada brand tertentu pada waktu yang berkesinambungan (Daikh, 2015). Konsumen dengan indikasi merasa setia akan mengonsumsi suatu produk pada brand tertentu melebihi kuantitas konsumen biasanya yang sekaligus akan merekomendasikan produk pada orang lain (Ngo \& Nguyen, 2016). Loyalitas konsumen penting karena dapat meningkatkan resistensi dari perusahaan dan dapat meningkatkan keuangan perusahaan (Hurriyati, 2016). Menurut (Susanti \& Kusumahati, 2020) customer loyalty dapat diukur dengan indikator sebagai berikut:

1. Pengulangan orderan.

2. Merekomendasikan produk.

3. Kurang memperhatikan brand lain.

4. Membeli produk lain di perusahaan yang sama.

5. Menawarkan ide atau jasa. 


\section{Kepuasan Konsumen}

Kepuasan adalah kondisi emosional seseorang akibat merasakan fakta yang ada dengan perbandingan pada ekspektasi sebelumnya (Kotler, 2012). Dengan mewujudkan rasa puas dari seseorang dapat memicu kemenangan pada persaingan pasar yang ada. Hal tersebut karena kepuasan seseorang dapat menyebabkan meningkatnya loyalitas konsumen pada suatu produk (Hasan \& Islam, 2020). Menurut (Tjiptono, 2012) kepuasan konsumen dapat diukur dengan indiktaor sebagai berikut:

1. Before sales satisfaction.

2. Product and price satisfaction.

3. After sales satisfaction.

4. Marketplace structure or performance satisfaction.

\section{HIPOTESIS}

Berdasarkan permasalahan yang telah dipaparkan sebelumnya, hipotesis dalam penelitian ini dapat dinyatakan sebagai berikut:

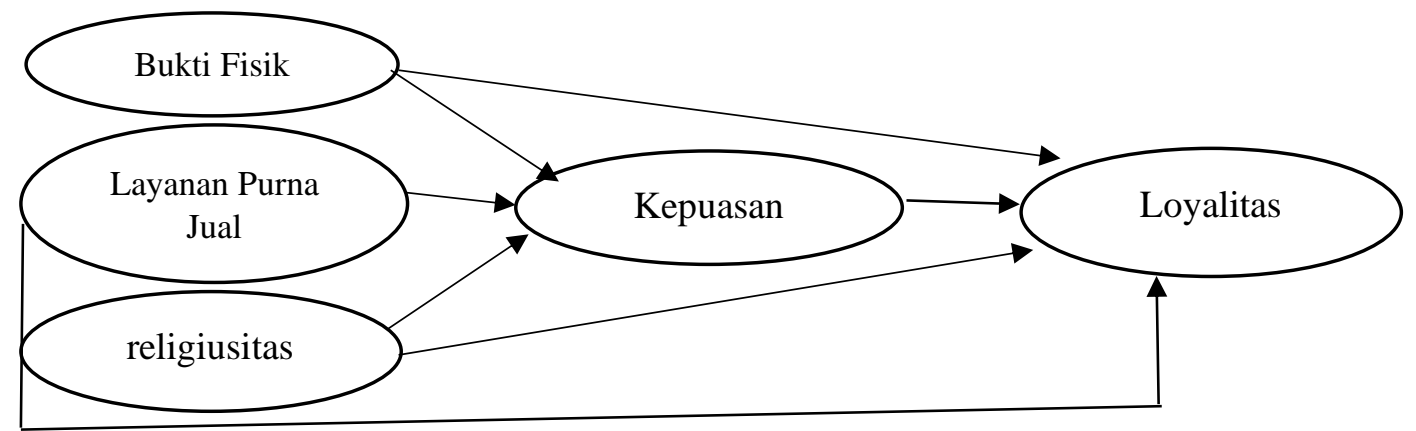

Gambar 1. Kerangka Konseptual

Berdasarkan model tersebut, dapat dilihat bahwasannya variabel bukti fisik, layanan purna jual, dan religiusitas berpengaruh secara positif dan signifikan terhadap loyalitas konsumen. Kemudian, kepuasan konsumen memiliki kedudukan sebagai variabel mediasi antara bukti fisik, layanan purna jual, dan religiusitas terhadap loyalitas konsumen.

\section{METODE PENELITIAN}

Jenis penelitian ini adalah penelitian kuantitatif yaitu penelitian yang menjelaskan dengan data statistik (Sugiyono, 2018). Populasi dari penelitian ini adalah Mahasiswa IAIN Salatiga yang tidak diketahui jumlahnya secara pasti (unknow population). Sampel diambil dengan teknik purposive sampling, yaitu pengambilan sampel dengan suatu kriteria tertentu (Anam et al., 2021). Kriterianya yaitu merupakan mahasiswa aktif IAIN Salatiga dan menjadi konsumen produk Rabbani dengan sedikitnya telah melakukan satu kali transaksi pembelian. Data yang didapat dari penyebaran kuesioner melalui google form kepada sejumlah sampel yang ditentukan yaitu dengan perhitungan (Anam et al., 2021) sebagai berikut:

$$
\mathrm{n}=\frac{z^{2} p q}{e^{2}}=\frac{1,96^{2}(0,5)(0,5)}{0,1^{2}}=96,04 .
$$

Data yang dibutuhkan sejumlah 96,04 dan dibulatkan menjadi 96 mahasiswa. Data yang telah didapat kemudian dianalisis dengan bantuan SPSS 2.3. pengujian yang dilakukan yaitu uji validitas, reliabilitas, uji $\mathrm{T}_{\text {test, }}$, uji $\mathrm{F}_{\text {test }}$, dan analisis jalur (path analysis). Pengujian uji validitas dan reliabiltas dilakukan untuk mengetahui layak tidaknya sebuah pertanyaan yang akan 
digunakan untuk uji selanjutnya (Sugiyono, 2018). Uji $\mathrm{F}_{\text {test }}$ dilakukan untuk menguji pengaruh variabel independen secara simultan. Sedangkan uji $\mathrm{T}_{\text {test }}$ dilakukan untuk menguji pengaruh variabel independen secara parsial. Uji-uji lainnya digunakan untuk menguji adanya permasalahan-permasalahan yang terjadi pada data yang dimiliki. Path analysis dilakukan untuk menguji pengaruh mediasi dari variabel kepuasan terhadap loyalitas konsumen, dengan model persamaan sebagai berikut:

Persamaan 1

$$
\mathrm{Z}=\beta 0+\beta 1 \mathrm{X} 1+\beta 2 \mathrm{X} 2+\beta 3 \mathrm{X} 3+e 1
$$

Persamaan 2

$$
\mathrm{Y}=\beta 0+\beta 1 \mathrm{X} 1+\beta 2 \mathrm{X} 2+\beta 3 \mathrm{X} 3+\beta \mathrm{Z}+e 2
$$

Keterangan :

$$
\begin{array}{llll}
\mathrm{Y} & =\text { customer loyalty } & \mathrm{X} 2 & =\text { after sale service } \\
\beta 0 & =\text { parameter koefisien regresi } & \mathrm{X} 3 & =\text { religiusitas } \\
\beta & =\text { konstanta persamaan regresi } & \mathrm{Z} & =\text { customer satisfaction } \\
\mathrm{X} 1 & =\text { physical evidence } & &
\end{array}
$$

\section{HASIL DAN PEMBAHASAN}

Analisis Deskriptif Responden

Konsumen Rabbani pada IAIN Salatiga baik kampus 1, kampus 2, dan kampus 3 didominasi oleh mahasiswa Fakultas Ekonomi dan Bisnis Islam. Gender perempuan menjadi mayoritas konsumen dengan konsumsi produk terbanyak adalah kerudung. Dengan frekuensi pembelian mayoritas sebanyak 1-2 kali.

\section{Uji Validitas dan Reliabilitas}

Item kuesioner dinyatakan reliabel apabila memiliki nilai cronbach's alpha lebih dari 0,6 dan dinyatakan valid apabila memiliki nilai score correlation lebih besar dari T tabel (df-2) yaitu 0,3610 (Alfiyani, 2021). Pada hasil pengujian data yang telah dilakukan, didapatkan nilai cronbach's alpha lebih dari 0,6 dan nilai score correlation lebih besar dari 0,3610. Sehingga seluruh variabel dinyatakan valid dan reliabel. Maka pengujian selanjutnya dapat dilanjutkan.

\section{Uji Koefisien Determinasi, $\mathbf{F}_{\text {test }}$ dan $\mathbf{T}_{\text {test }}$}

Koefisien determinasi memiliki nilai $\mathrm{R}$ square sebesar 0,499 sehingga ditunjukkan besar

\begin{tabular}{|c|c|c|c|c|c|c|}
\hline \multirow{2}{*}{\multicolumn{2}{|c|}{ Model }} & \multicolumn{2}{|c|}{$\begin{array}{c}\text { Unstandardized } \\
\text { Coefficients }\end{array}$} & \multirow{2}{*}{$\begin{array}{c}\begin{array}{c}\text { Standardized } \\
\text { Coefficients }\end{array} \\
\text { Beta }\end{array}$} & \multirow[b]{2}{*}{$\mathrm{T}$} & \multirow[b]{2}{*}{ Sig. } \\
\hline & & $\mathrm{B}$ & Std. Error & & & \\
\hline 1 & (Constant) & 4,556 & 6,279 & &, 725 & ,470 \\
\hline & Physical Evidence & ,097 & , 195 & ,049 & , 498 & 620 \\
\hline & After Sale Service &, 363 & , 123 &, 276 & 2,947 & ,004 \\
\hline & Religiusitas &,- 177 & , 129 &,- 112 & $-1,369$ &, 174 \\
\hline & $\begin{array}{l}\text { Customer } \\
\text { Satisfaction }\end{array}$ & ,736 & , 134 &, 531 & 5,485 &, 000 \\
\hline
\end{tabular}
pengaruh pada loyalitas sebesar 0,499 atau 49,9\% dan sisanya yaitu 0,501 atau 50,1\% dipengaruhi oleh variabel lain yang tidak diteliti pada penelitian ini. Nilai signifikansi pada tabel uji $F_{\text {test }}$ menunjukkan nilai sebesar 0,000 yang berarti bukti fisik, layanan purna jual, dan religiusitas mempengaruhi loyalitas konsumen secara bersama-sama.

Tabel 1. Hasil Uji T

a. Dependent Variable: Customer Loyalty 
Dasar pengambilan keputusan pada uji $\mathrm{T}_{\text {test }}$ yaitu nilai signifikansi $<0,05$ atau $\mathrm{t}$ hitung $>\mathrm{t}$ tabel yang berarti terdapat pengaruh dari variabel independen terhadap variabel dependen secara parsial. Berdasarkan pengujian, bukti fisik menunjukkan nilai koefisien sebesar 0,097 dan nilai signifikansi sebesar 0,620 >0,05 maka bukti fisik berpengaruh positif dan tidak signifikan terhadap loyalitas konsumen. Layanan purna jual memiliki nilai koefisien sebesar 0,363 dan nilai signifikansi sebesar $0,04<0,05$ maka variabel layanan purna jual memiliki pengaruh yang positif dan signifikan terhadap loyalitas konsumen. Religiusitas memiliki nilai koefisien sebesar -0,177 dan nilai signifikansi sebesar $0,174>0,05$ maka variabel religiusitas memiliki pengaruh yang negatif dan tidak signifikan terhadap loyalitas konsumen. Kepuasan konsumen memiliki nilai koefisien sebesar 0,736 dan nilai signifikansi sebesar $0,000<0,05$ maka variabel kepuasan konsumen memiliki pengaruh yang positif dan signifikan terhadap loyalitas konsumen.

\section{Uji Path Analysis}

Persamaan I

$$
\mathrm{Z}=2,623+0,730+0,177+0,092+e 1
$$

Berdasarkan output regresi pada persamaan I, didapatkan hasil : 1) Nilai konstanta 2,623 yang mengandung arti bahwa bukti fisik (X1), layanan purna jual (X2), religiusitas (X3), konstanta $(X 1, X 2, X 3=0)$ maka, variabel kepuasan konsumen berada pada tingkat 2,623.2) Nilai signifikansi pada variabel bukti fisik sebesar $0,000<0,05$, nilai signifikansi pada variabel layanan purna jual sebesar $0,063>0,05$, dan nilai signifikansi pada variabel religiusitas yaitu sebesar $0,357>0,05$. Artinya, bukti fisik berpengaruh signifikan terhadap kepuasan konsumen, sedangkan layanan purna jual dan religiusitas tidak memiliki pengaruh yang signifikan terhadap Z. 3) Koefisien regresi bukti fisik sebesar 0,730 dengan nilai signifikansi yaitu 0,000<0,05. Artinya bukti fisik memiliki pengaruh signifikan pada kepuasan konsumen. 4) Koefisien layanan purna jual sebesar 0,177 dengan nilai signifikansi sebesar 0,063>0,05. Artinya, tidak terdapat pengaruh layanan purna jual terhadap kepuasan konsumen. 5) Koefisien religiusitas sebesar 0,092 dengan nilai signifikansi yaitu sebesar 0,357>0,05. Artinya, religiusitas tidak mempengaruhi peningkatan kepuasan konsumen. 6) Besarnya nilai $\mathrm{R}^{2}$ (R Square) pada tabel model summary adalah sebesar 0,412. Artinya, sumbangan kontribusi pada bukti fisik, layanan purna jual dan religiusitas terhadap kepuasan konsumen sebesar 0,412 sementara sisanya yaitu 0,588 dipengaruhi oleh kontribusi dari variabel lain yang tidak diteliti. Maka besarnya $e 1$ adalah $e 1=\sqrt{(1-0,412)}=0,766$.

Persamaan II

$$
\mathrm{Y}=4,556+0,097+0,363+(-0,177)+0,736+e 2
$$

Hasil output pada regresi persamaan II yakni memberikan hasil bahwa: 1) Konstanta 4,556 mengandung arti apabila bukti fisik, layanan purna jual, dan religiusitas memiliki konstanta $(\mathrm{X} 1, \mathrm{X} 2, \mathrm{X} 3=0)$ maka variabel customer loyalty berada pada tingkat 4,556. 2) Nilai signifikansi dari variabel $\mathrm{X} 1, \mathrm{X} 2, \mathrm{X} 3$, dan $\mathrm{Z}$ terhadap Y yaitu variabel bukti fisik (X1) sebesar 0,620 > 0,05, layanan purna jual (X2) 0,004 < 0,05, religiusitas (X3) sebesar 0,174, dan kepuasan konsumen (Z) sebesar 0,000. Maka, hal ini menunjukkan bahwa terdapat pengaruh yang signifikan dari variabel X2 dan Z terhadap Y, sedangkan variabel X1 dan X3 tidak memberikan pengaruh yang positif dan signifikan terhadap Y. 3) Koefisien regresi bukti fisik sebesar 0,097 dengan nilai signifikansi sebesar 0,620 >0,05. Maka, kenaikan bukti fisik tidak mempengaruhi peningkatan loyalitas konsumen. 4) Koefisien regresi layanan purna jual sebesar 0,363 dengan nilai signifikansi sebesar 0,004 < 0,05. Maka, kenaikan layanan purna jual memberikan kontribusi atas naiknya loyalitas konsumen. 5) Koefisen regresi religiusitas sebesar -0,177 dengan nilai signifikansi sebesar $0,174>0,05$. Maka, tidak ada pengaruh dari kenaikan poin variabel religiusitas terhadap loyalitas konsumen. 6) Koefisien regresi kepuasan konsumen sebesar 0,736 
dengan nilai signifikansi sebesar $0,000<0,05$. Maka, setiap kenaikan kepuasan konsumen akan meningkatkan loyalitas konsumen. 7$)$ Nilai $\mathrm{R}^{2}$ ( $R$ square) yang terdapat pada model summary path analysis yaitu 0,499. Artinya, X1,X2,X3, dan Z mempengaruhi Y sebesar 0,499. Sementara itu, 0,501 dipengaruhi oleh kontribusi dari variabel lain yang tidak diteliti. Maka, diperoleh nilai $e 2$ sebesar 0,707 dengan persamaan $e 2=\sqrt{1-0,499}=0,707$.

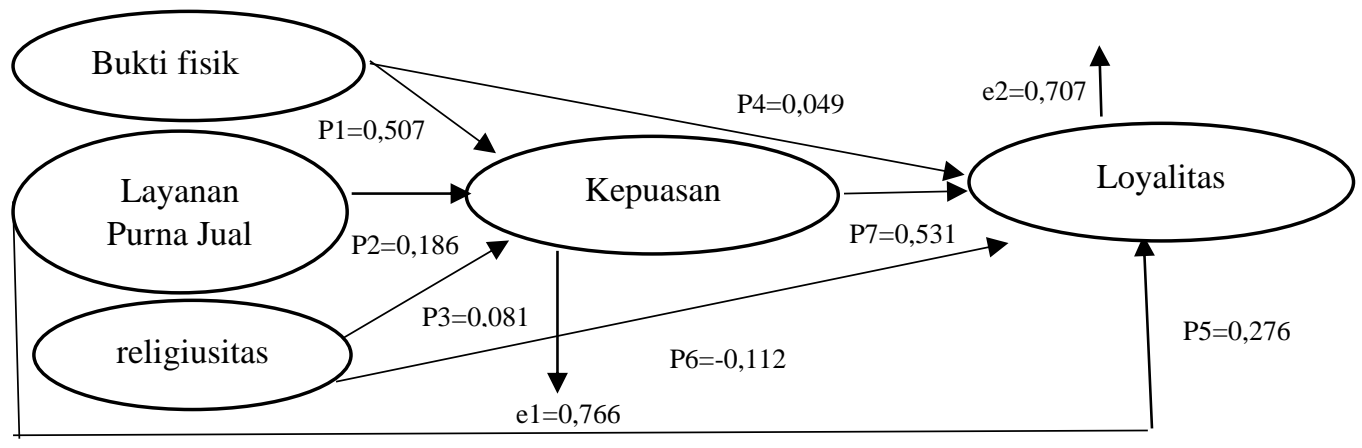

Gambar 2. Model Analisis Jalur

\section{Pembahasan}

Hipotesis pertama menyatakan bahwa bukti fisik berpengaruh positif dan signifikan terhadap kepuasan konsumen, diterima. Hasil penelitian ini menunjukkan hasil bahwa bukti fisik berpengaruh positif signifikan terhadap kepuasan konsumen. Physical evidence mencakup seluruh aspek meliputi tempat, dekorasi, karyawan, sarana dan prasarana yang berhubungan dengan pelayanan perusahaan terhadap konsumen (Othman, Harun, et al., 2020). Sehingga bukti fisik pada Rabbani Store itu berperan penting untuk dapat meningkatkan kepuasan yang telah diekspektasikan terlebih dahulu sebelum transaksi terjadi.

Hipotesis kedua menyatakan bahwa layanan purna jual berpengaruh positif dan signifikan terhadap kepuasan konsumen, ditolak. Hasil penelitian ini menunjukkan pengaruh yang positif dan tidak signifikan. Sejalan dengan penelitian (Dery et al., 2020) yang menyatakan bahwa pengaruh kualitas produk, harga, citra merek, dan layanan purna jual terhadap kepuasan konsumen dengan memberikan hasil layanan purna jual tidak memiliki pengaruh terhadap kepuasan. Layanan purna jual adalah tawaran perusahaan dalam rangka usaha pemuasan konsumen yang mudah luntur.

Hipotesis ketiga menyatakan bahwa religiusitas berpengaruh positif dan signifikan terhadap kepuasan konsumen, ditolak. Hasil penelitian ini menunjukkan pengaruh yang positif dan tidak signifikan. Tidak semua orang memiliki pemahaman religiusitas yang sama dan tidak semua yang berkeyakinan sama memiliki selera dan pilihan produk yang sama. Sehingga, religiusitas tidak berpengaruh signifikan pada loyalitas pembeli (Patria, 2021). Pada kasus ini, penurunan dari tingkat religiusitas konsumen Rabbani tidak mempengaruhi kepuasan yang dirasakan dari konsumen itu sendiri. Tingkat kepuasan pembeli dipengaruhi oleh variabel lain.

Hipotesis keempat menyatakan bahwa bukti fisik berpengaruh positif dan signifikan terhadap loyalitas konsumen, ditolak. Hasil penelitian ini menunjukkan pengaruh yang positif dan tidak signifikan. Dimensi kualitas pelayanan, termasuk bukti fisik tidak mempengaruhi kepuasan konsumen yang berdampak pada loyalitas (Aprilianti et al., 2019). Konsumen yang merasa puas karena bukti fisik yang telah diterima tidak menjadikan konsumen menjadi loyal. Hal ini menunjukkan, loyalitas konsumen pada toko Rabbani dipengaruhi oleh aspek lain yang tidak dibahas dalam penelitian ini. 
Hipotesis kelima menyatakan bahwa "layanan purna jual berpengaruh positif dan signifikan terhadap loyalitas konsumen", diterima. Hasil penelitian ini menunjukkan pengaruh yang positif dan signifikan. Sehingga dapat disimpulkan bahwa layanan purna jual berpengaruh positif dan signifikan terhadap loyalitas konsumen. Pelayanan merupakan segala usaha dan kegiatan perusahaan untuk pemenuhan keinginan konsumen (Aprilianti et al., 2019). Konsumen Rabbani mengungkapkan bahwa mereka merasa pelayanan purna jual dari Rabbani Store cukup membuat mereka menjadi kembali untuk melakukan transaksi kembali pada store yang sama.

Hipotesis keenam menyatakan bahwa religiusitas berpengaruh positif dan signifikan terhadap loyalitas, ditolak. Hasil penelitian ini menunjukkan pengaruh yang negatif dan tidak signifikan. Temuan ini mengindikasikan adanya perbedaan persepsi mengenai religiusitas pada tiap-tiap konsumen yang membeli produk Rabbani (Pangarso, 2018). Sebagain dari konsumen memutuskan untuk membeli busana muslim pada Rabbani Store dikarenakan oleh beberapa faktor lain seperti mengikuti trend, mengimbangi zaman, dan memenuhi kebutuhan spiritual pada event tertentu saja. Namun, hal ini tidak mempengaruhi rasa loyalitas konsumen pada Rabbani.

Hipotesis ketujuh menyatakan bahwa kepuasan konsumen berpengaruh positif dan signifikan terhadap loyalitas konsumen, diterima. Hasil penelitian ini menunjukkan pengaruh yang positif dan signifikan (Pras \& Sumadi, 2020). Hasil ini memberikan asumsi bahwa kepuasan konsumen pada Rabbani Store membuat konsumen melakukan transaksi kembali pada lain waktu. Dengan memelihara konsumen lama akan mengurangi biaya untuk mencari pelanggan (biaya promosi,iklan, diskon, dll). Pelanggan yang telah merasakan puas, akan secara otomatis membeli produk dengan kuantitas yang lebih besar daripada konsumen biasanya.

Hipotesis kedelapan menyatakan bahwa kepuasan konsumen mampu menjadi mediasi variabel bukti fisik terhadap loyalitas konsumen, ditolak. Hasil penelitian ini menunjukkan pengaruh yang positif dan tidak signifikan. Sehingga dapat disimpulkan bahwa customer satisfaction tidak mampu menjadi mediasi dari variabel bukti fisik terhadap loyalitas konsumen. Meskipun penelitian yang dilakukan oleh (Othman, Weijun, et al., 2020), menunjukkan hasil bahwa bukti fisik memiliki pengaruh yang positif dan signifikan baik secara langsung maupun tidak langsung. Namun, penelitian ini tidak berhasil menunjukkan adanya hasil penelitian yang serupa.

Hipotesis kesembilan menyatakan bahwa kepuasan konsumen mampu menjadi mediasi layanan purna jual terhadap loyalitas konsumen, diterima. Hasil penelitian ini menunjukkan pengaruh yang positif dan signifikan. Sehingga dapat disimpulkan bahwa after sale service berpengaruh positif dan signifikan terhadap loyalitas konsumen melalui kepuasan konsumen sebagai mediasi. Sejalan dengan penelitian terdahulu yang telah dilakukan oleh (Dean et al., 2021; Hussein \& Hartelina, 2021; Lase, 2020; Othman, Weijun, et al., 2020) menyatakan hasil penelitian bahwa terdapat adanya pengaruh yang positif dan signifikan dari adanya layanan purna jual terhadap customer loyalty.

Hipotesis terakhir menyatakan bahwa kepuasan konsumen mampu menjadi mediasi variabel religiusitas terhadap loyalitas konsumen, ditolak. Hasil penelitian ini menunjukkan pengaruh yang negatif dan tidak signifikan. Hasil penelitian menggambarkan bahwa religiusitas tidak mempengaruhi tingkat loyalitas konsumen Rabbani. Pembelian muslim fashion tidak selalu karena tingkat religiusitas konsumen yang tinggi. Kemudian, tingkat religiusitas pada konsumen Rabbani dalam penelitian ini menunjukkan hasil bahwa konsumen yang merasa puas dan memutuskan untuk menjadi kosumen yang setia tidak berdasarkan tingkat kedalaman ilmu agamanya (Patria, 2021). 


\section{PENUTUP \\ Simpulan}

Berdasarkan hasil uji-uji yang telah dilakukan meliputi Uji $\mathrm{T}_{\text {test, }} \mathrm{Uji}_{\mathrm{t}}$ test, $\mathrm{Uji}$ Path Analysis maka diperoleh simpulan bahwa bukti fisik berpengaruh terhadap kepuasan konsumen, layanan purna jual dan kepuasan konsumen terhadap loyalitas konsumen berpengaruh positif dan signifikan; layanan purna jual terhadap kepuasan konsumen tidak berpengaruh; religiusitas dan bukti fisik terhadap loyalitas konsumen tidak berpengaruh; serta kepuasan konsumen tidak mampu menjadi mediasi variabel bukti fisik, layanan purna jual, dan religiusitas terhadap loyalitas konsumen.

Dengan demikian, penelitian ini berhasil membuktikan bahwa bukti fisik dan layanan purna jual perlu diperhatikan karena dapat mempengaruhi kepuasan konsumen dimana kepuasan konsumen yang semakin baik akan berdampak pada loyalitas konsumen yang semakin meningkat pula. Sehingga penting untuk Rabbani memperhatikan bukti fisik yang ditawarkan untuk konsumen, adanya tanggung jawab setelah transaksi pembelian berlangsung seperti kelengkapan aksesoris pendukung, kemudahan memperoleh suku cadang, waktu garansi pengembalian, konsultasi lanjutan dan juga jumlah layanan yang mudah ditemukan. Akan tetapi, penelitian ini tidak berhasil mengungkapkan adanya pengaruh dari layanan purna jual yang berarti kepuasan dari pelanggan Rabbani tidak dipengaruhi dari pelayanan setelah pembelian yang diberikan oleh perusahaan. Tingkat religiusitas, bukti fisik, dan layanan purna jual tidak mempengaruhi loyalitas dari pelanggan Rabbani. Kepuasan tidak mampu menjadi variabel yang dapat menjadi jalan dari bukti fisik, layanan purna jual, dan religiusitas agar mempertahankan retensi dari loyalitas perusahaan Rabbani itu sendiri.

\section{Saran}

Penelitian ini dilakukan saat masa pandemi dengan memanfaatkan google form dalam penyebaran kuesioner, sehingga kemungkinan adanya human error lebih banyak. Serta penelitian ini hanya menggunakan beberapa variabel yang terdapat pada marketing mix, diharapkan peneliti selanjutnya dapat menyempurnakan dengan menambahkan variabel yang lebih kompleks. Saran untuk perusahaan Rabbani agar lebih memperhatikan kualitas dari pelayanan yang diberikan untuk konsumen. Sebagaimana hasil dari penelitian ini, konsumen Rabbani memperhatikan adanya pelayanan dalam bentuk fisik dan rasa puas setelah transaksi pembelian berlangsung. Saat konsumen merasa puas dengan the best effort yang diberikan, secara tidak langsung akan mendorong mereka membantu kemajuan dari perusaan Rabbani sendiri. Baik dengan pengulangan order, promosi dengan word of mouth, pemberian kritik dan saran yang membangun, serta ide yang dapat meningkatkan progress pada Rabbani Store.

\section{REFERENSI}

Ajzen, I. (2005). attitudes, personality and behaviour (second edition). Open University PressMcGraw Hill Education.

Alfiyani, F. (2021). Pengaruh Kualitas Layanan, Kualitas Produk, dan Implementasi Corporate Sosial Responsibility (CSR) terhadap Loyalitas Nasabah dengan Kepuasan Nasabah Sebagai Variabel Intervening. Skripsi.

Anam, M. S., Nadila, D. L., Ayu, A. T., \& Rosia, R. (2021). Pengaruh Kualitas Produk, Harga, dan Brand Image terhadap Keputusan Pembelian Produk Hand and Body Lotion Merek Citra (Studi Kasus Pada Mahasiswa IAIN Salatiga). Jurnal Ekonomi Dan Ekonomi Syariah, 4(1).

Aprilianti, A. R., Budiawati, H., \& Kasno. (2019). Pengaruh Dimensi Kualitas Pelayanan Kesehatan Terhadap Kepuasan Pasien Pengguna BPJS Di Puskesmas Wonorejo Kencong Kabupaten Jember. Proceeding Progress Conference, 2(1).

Arif, M. N. R. (2012). Dasar-Dasar Pemasaran Bank Syariah. Alfabeta. 


\section{JURNAL EKOBIS: EKONOMI, BISNIS \& MANAJEMEN}

Vol 11 Nomor 2 (2021)

Bawono, A., \& Oktaviani, M. F. R. (2016). Analisi Pemahaman, Produk, dan Tingkat Religiusitas terhadap Keputusan Mahasiswa IAIN Menjadi Nasabah Bank Syariah Cabang Salatiga. Muqtasid: Jurnal Ekonomi Dan Perbankan Syariah, 7(1), 29-53.

Daikh, J. (2015). A Research Proposal: The Relationship Between Customer Satisfaction and Consumer Loyalty.

Dean, J. P., Irda, \& Purbo, J. (2021). Pengaruh Manajemen Relasi Pelanggan, Nilai Pelanggan, dan Layanan Purna Jual Terhadap Kepuasan Pelanggan Auto 2000 Kota Padang.

Dery, A. P., Ice, K., \& Lindawati. (2020). Pengaruh Kualitas Produk, Harga, Citra Merek dan Layanan Purna Jual Terhadap Kepuasan Konsumen (Studi Pada Pengguna Sepeda Motor Yamaha Nmax di Kota Padang.

Fauziyah, A. N., \& Tjahjaningsih, E. (2021). Membangun Kepuasan Pelanggan Indihome Telkom Witel Kudus dengan Meningkatkan Persepsi Harga, Layanan Purna Jual, dan Promosi. Proceeding SENDIU 2021.

Hasan, M., \& Islam, M. F. (2020). The Effect of Marketing Mix (7Ps') on Tourists' Satisfaction: A Study on Cumilla. The Cost and Management, 48(2).

Hatauruk, M. R., Ghozali, I., Aprianti, D. I., Reonald, N., \& Musthofa, A. (2020). Marketing Mix and Customer Satisfaction in its Role Toward Customer Loyalty Throught Environmental Accounting Moderation. International Journal of Scientific \& Technology Research, 9(3).

Hurriyati. (2016). Marketing Rules and Customer Loyalty. Alfabeta.

Hussein, F., \& Hartelina. (2021). After Sale Service for Smartphone Iphone To Cutomer Loyalty. Aptisi TRansaction on Management, 5(1), 62-72.

Hutagalung, D., Asbari, M., Fayzhall, M., Ariyanto, E., Agistiawati, E., Sudiyono, R. N., Waruwu, H., Goestjahjanti, F. S., Winanti, \& Yuwono, T. (2020). Peran Religiusitas, Kepemimpinan Transformasional, Kepuasan Kerja, dan Mediasi Organizational Citizenship Behaviour terhadap Kinerja Guru. Jurnal of Education, Phsychology and Counseling, 2(1).

Jalil, M. (2011). Customer Information Driven After Sales Management: Lesson from Spare Parts Logistics.

Khatab, J. J., Esmaeel, E. S., \& Othman, B. (2019). Dimentions of Service Marketing Mix and Its Effects on Customer Satisfaction: A Case Study of International Kurdistan Bankin Erbil City-Iraq. Test Engineering \& Management, 81, 4846-4855.

Kotler, K. (2012). Marketing Manajemen. Pearson Education Limited.

Lase, A. Y. P. (2020). Pengaruh Pelayanan Purna Jual Terhadap Loyalitas Konsumen Pada Asus Service Center Kota Jambi. Science of Management and Students Research Journal (SMS), 1(6), 221-228.

Lestari, M. M., Lie, D., Efendi, \& Halim, F. (2021). Pengaruh Kualitas Pelayanan Terhadap Loyalitas Pelanggan Dengan Kepuasan sebagai Variabel Intervening Pada Bengkel Anugerah Perumnas Batu Enam. Journal of Management Science, 1(1).

Lupiyoadi, R. (2002). Edisi Pertama Manajemen Pemasaran Jasa: Teori dan Praktik. Salemba Empat.

m.rabbani.co.id. (2021). Tentang Kami. Http://M.Rabbani.Co.Id/, diakses pada tanggal 2 Maret 2021 pukul 14.15 WIB.

Munandar, A., \& Sari, N. (2019). Pengaruh Religiusitas, Kualitas Pelayanan, Kualitas Produk terhadap Loyalitas Nasabah Tabungan Pada PT. Bank Aceh Syariah Kantor Cabang Pembantu Darussalam. Jurnal Hukum Dan Ekonomi Syariah, 4(2), 101-120.

Nasution, I. A., Fauzi, A., \& Wibowo, R. P. (2020). The Effect of Marketing Mix on Customer Satisfaction in Belawan Branch of PT Pelabuhan Indonesia 1 (Persero) Medan. International Journal of Research and Review, 7(1).

Ngo, V. M., \& Nguyen, H. H. (2016). The Relationship Between Service Quality, Customer Satisfaction, and Customer Loyalty: An Investigation in Vietnamese Retail Banking Sector. Journal of Competitiveness, 8(2).

Olivia, G. R., \& Ngatno. (2021). Pengaruh Kualitas Produk dan Promosi terhadap Loyalitas 
Pelanggan melalui Kepuasan Pelanggan sebagai Variabel Intervening. Jurnal Administrasi Bisnis, 10(1).

Othman, B., Harun, A., Sadq, Z. M., Rashid, W. N., Abdullah, K. M., Mohammed, H. O., \& Faeq, D. K. (2020). Effects of Service Marketing Mix on Umrah Customer Satisfaction: Empirical Study on Umrah Traveling Industry in Malaysia. Test Engineering \& Management, 83, 22895-22909.

Othman, B., Weijun, H., Huang, Z., Taha, M. Y., Xi, J., \& Ramsey, T. (2020). Integrating After Sale Service into the Traditional Marketing Mix Model. Their Effects on Service Value and Customer Retention towards Clothing Store Brands in China. Revista Argentina de Clinica Psicologica, 29(5), 19-34.

Pangarso, P. P. (2018). Analisis Pengaruh Kualitas Pelayanan dan Religiusitas Terhadap Kepuasan dan Loyalitas Nasabah Koperasi Simpan Pinjam dan Pembiayaan Syariah (KPPS) di Yogyakarta.

Patria, N. A. E. (2021). Pengaruh Citra Merek, Kualitas Pelayanan, dan Religiusitas Terhadap Loyalitas Pelanggan dengan Variabel Kepuasan Konsumen Sebagai Variabel Intervening di Soto Segeer Hj Fatimah.

Pras, P. P. P., \& Sumadi. (2020). Islamic Microfinance Service Quality and Its Impact on Yogyakarta Customer's Satisfaction. International Jurnal of Science, 1(2), 127-132.

Rasida. (2020). Pengaruh Marketing Mix Terhadap Keputusan Pembelian Konsumen Gamis Rabbani Hijab Syar'i. Skripsi.

Saputro, W. A., \& Laura, N. (2020). Pengaruh Digital Marketing dan Layanan Purna Jual terhadap Keputusan Pembelian yang Dimoderasi Oleh Citra Perusahaan. Media Manajemen Jasa, $8(2)$.

Setio, S., \& Wahjudono, D. B. K. (2017). Pengaruh Marketing Mix Terhadap Kepuasan dan Loyalitas Customer Hotel Amaris Darmo Surabaya. Jurnal Ekonomi Dan Keuangan, 4(3).

Sugiyono. (2018). Metode Penelitian Kuantitatif.

Susanti, F., \& Kusumahati, W. (2020). Pengaruh Kualitas Produk dan Brand terhadap Loyalitas Konsumen (Studi Pada Konsumen Pengguna Produk "Tupperware" di Kelurahan Bandar Buat Padang). Jurnal Pundi, 4(2).

Tjiptono, F. (2012). Strategi Pemasaran. ANDI.

Trishananto, Y. (2019). Islamic Branding, Religiosity, and Consumer Decision On Product in IAIN Salatiga. Indonesian Jurnal of Islamic Economics Research, 1(2), 93-100.

Wicaksono, R. M. S. P., Saroh, S., \& Zunaida, D. (2021). Analisis Pengaruh Physical Evidence, price Discount, People, dan Packaging terhadap Impulse Buying Pada Produk Kuliner. JIAGABI, 10(1).

Yusman, al'rafi fulqi, \& Yateno. (2021). Pengaruh Bukti Fisik, Kehandalan, dan Jaminan terhadap Kepuasan Konsumen dalam Penggunaan Digital Payment Dana pada Mahasiswa FEB UM Metro. Jurnal Manajemen DIVERSIFIKASI, l(2).

Zainurossalamia, S. (2020). Manajemen Pemasaran: Teori dan Strategi. Forum Pemuda Aswaja. 